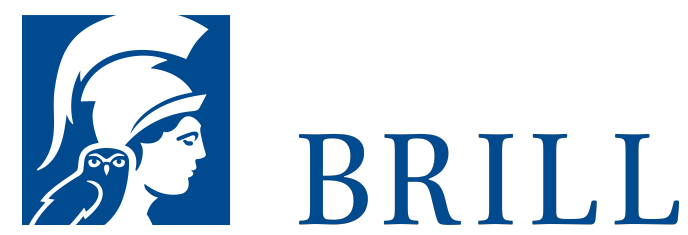

\title{
Jerusalem - Heilige Stätten der Juden
}

\section{Author: Miriam Magall}

Miriam Magall lädt ein zur Entdeckung der heiligen Stätten der Juden in Jerusalem. Ihr Buch führt den Leser durch die jüdische Geschichte der heiligen Stadt, von alten und neuen Orten des Gebets bis hin zu Orten der ewigen Ruhe, seien es die über 2000 Jahre alten Grabstätten auf dem Ölberg, die Grabkammern der Könige oder die Gräber jüngst Verstorbener aus dem letzten Jahrhundert auf dem Herzl-Berg. Ein wunderbares Buch, das die mit Jerusalem so eng verbundene jüdische Geschichte auf besondere Weise in den Mittelpunkt rückt.

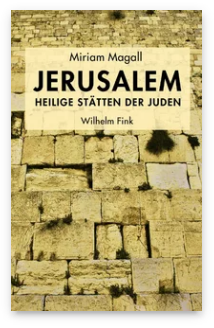

Pages: 190

Seiten, $66 \mathrm{~s} / \mathrm{w}$ und 29 farb. Abb.

Language:

German

Subjects:

Cultural History,

Literature and

Cultural Studies

Publisher: Brill |

Fink

E-Book (PDF)

Released online:

o1 Feb 2012

ISBN: 978-3-

8467-5039-1 
For more information see brill.com

Order information: Order online at brill.com +44330 333 0049 | customerservices@brill.com Submission information: brill.com/authors

Titles published by Brill | Fink, Brill | mentis or Brill | Schöningh: +49(o)715413279216| brill@brocom.de 